\title{
THE ROLE OF MALAYSIAN AND INDONESIAN ULAMA IN HADITH STUDIES: Muhammad Idris al-Marbawi and T.M. Hasbi Ash Shiddieqy
}

\author{
Ramli Abdul Wahid \\ Universitas Islam Negeri Sumatera Utara Medan \\ Jl. Willem Iskandar Pasar V Medan Estate, Medan, Sumatera Utara, 20371 \\ e-mail: ramliabdulwahid@gmail.com
}

A. Irwan Santeri Doll Kawaid

Universiti Sains Islam Malaysia

Bandar Baru Nilai, 71800 Nilai, Negeri Sembilan, Malaysia

e-mail: a.irwan@usim.edu.my

\begin{abstract}
This study compares the roles of Muhammad Idris alMarbawi from Malaysia and Muhammad Hasbi Ash Shiddieqy from Indonesia in the field of hadith. Both scholars were considered to have contributed to the study of hadith in respective countries. This study is a literature study, the data of which was obtained through documentary study. The works of the two scholars were used as primary sources and the the previous researches of expert on the two scholars were used as secondary sources. This study found that both scholars had involved in hadith studies and left a number of important works in the field. The authors also found that the two scholars who lived in the same period but in a different country also wrote in other Islamic fields, especially Qur'anic exegesis and Islamic law, in addition to hadith. The difference is that al-Marbawi developed the study of sufism, while Ash Shiddieqy had never wrote in this field.
\end{abstract}

Keywords: hadith, ulama, Malaysia, Indonesia 


\section{Introduction}

Stemming from the scientific aspects, the development of hadith or prophetic tradition disciplines has not been proportionately attracted the attention of scholars in the archipelago. However, the disciplines of sufism, jurisprudence, theology and Qur'anic exegesis are relatively more developed. In fact, there are many works produced by Nusantara ulama in different fields. It is ironic that the study of hadith is left behind when compared to other fields of Islamic studies. After approximately a century and a half the facts show that the development of hadith studies and the science of hadith in Indonesia skyrocketed to the point of upheaval and even struggle between two contradicting forces of defenders and challengers. However, recent developments in the study of hadith have indeed begun to show a better direction. The existence of Islamic colleges, madrassas, and pesantren makes the study of hadith and the science of hadith increasingly preserved and developed.

The development of hadith studies in the archipelago could indeed not be separated from the existence and role of scholars who pursue this field. For example, Muhammed Idris al-Marbawi (1896-1989) from Malaysia was known as a prominent scholar, and he was considered an ulama in the field of hadith, despite having comprehensive understanding in the fields of Arabic, Qur'anic exegesis, fiqh and sufism. In Indonesia, on the other hand, there are many scholars who are considered experts in the field of hadith, including Muhammad Hasbi Ash Shiddieqy (1904-1975) who wrote in various fields of Islam as al-Marbawi, including Qur'anic exegesis, hadith and fiqh. From the aspect of the period, these two scholars of hadith can be said to have lived in the same era and both of whom have many similarities and differences. The most striking similarity between the two scholars is writing in the areas of Qur'anic exegesis, hadith and 
fiqh. Both scholars, clearly, made important contributions to sustainability and progress in the field of hadith studies both in Malaysia and Indonesia.

This study examines the comparison of the roles of Muhammad Idris al-Marbawi and Muhammad Hasbi Ash Shiddieqy in the field of hadith. The focus of this study is the intellectual biography and the role of the two scholars in the field of hadith. At first glance, it will be seen the similarities and differences between the two scholars, especially in the development of Islamic sciences. This study is a literature study where data is obtained through document study, both primary and secondary sources. The primary source in this study is of course the works of the two scholars, while the secondary source is the result of the study of experts on both scholars. The data obtained will be analyzed by the content analysis method. This study is of course expected to provide an overview of the role of the two scholars in the development of hadith studies in Southeast Asia.

Some researchers have indeed examined the two scholars discussed in this study. Among those studying al-Marbawi are Faisal Ahmad Shah, ${ }^{1}$ Latifah Abdul Majid and Nurullah Kurt, ${ }^{2}$ and Nor Azlida Aziz. ${ }^{3}$ On the other hand, researches conducted pertaining to Ash Shiddieqy amongst the most important are by Andi Miswar, ${ }^{4}$ Aan Supian, ${ }^{5}$ A.M. Ismatulloh, ${ }^{6}$ Masnun Tahir, Gatot Suhirman, ${ }^{8}$ and Fikri Hamdani. ${ }^{9}$ The studies they conducted, on the main, examined the ideas of each ulama without making comparisons with other figures. This is the main focus of this study in which the comparison between the role of al-Marbawi and Ash Shiddieqy in the study of hadith in their respective countries will be seen, and it is on this aspect lies the novelty of this study. 


\section{Shaykh Muhammad Idris al-Marbawi}

Muhammad Idris bin Abdul Rauf al-Marbawi al-Azhari was born in Mecca, 28 Zulkaedah 1313 of Islamic calendar. The al-Marbawi title was taken from the name of the village of his family origin in Lubuk Merbau, Kuala Kangsar, Perak, Malaysia and al-Azhari based on al-Azhar University Cairo, Egypt where he studied. Al-Marbawi himself was born in the village of Masfalah, Mecca, Saudi Arabia. He died at Hospital Besar Ipoh, Malaysia on October 13, 1989 at the age of 93. Shaykh Muhammad Idris al-Marbawi was the first ulama to write about the Sunan alTirmidzi tradition in the Malay language at length. ${ }^{10}$ Al-Marbawi received his religious education in Mecca. At the age of four, he was able to put the Qur'an into his memory. Two years later, he entered the Masfalah school, Mecca, which is located close to his home. In 1902, his family returned to Malaysia where he studied at the Malay School of Lubuk Merbau, Perak. Then, he continued to explore the Islamic sciences in Pondok Shaykh Wan Muhammad School in Bukit Chandan, Kuala Langsa, then Pondok Hussain al-Mas'udi in Kedah, then studied at Pondok Shaykh Ahmad Fathani in Bukit Mertajam, and finally at Pondok Tok Recognize in Kelantan. He studied various Islamic disciplines, including all branches of Arabic, especially na $\underline{h} w$ and sharf. After completing his studies, he was once an Islamic religious teacher in Perak. ${ }^{11}$

To fulfill his enthusiasm in acquiring knowledge, al-Marbawi decided to continue his studies to pursue further studies in Islamic sciences at Al-Azhar University in May 1924. While in Egypt, he studied with a number of scholars, especially in the field of hadith. He participated in the study circle of the hadith held by Shaykh Muhammad Ibrâhîm al-Samaluti who was an Islamic hadith scholar whose scientific knowledge is directly connected to Imam al-Bukhârî. To al-Samaluti, he delved in 
depth with al-Jâmi' al-Shahîh by Imam al-Tarmidzi, for the reason of which, he was able to translate it into Malay language. Then, he studied with Shaykh Mahmûd Ghunaym (scholar of Hanafi school), Shaykh Muhammad Bahith, Shaykh Abu alA'la al-Falaki (astronomer), Shaykh Muhammad 'Ali al-Mâliki, Shaykh 'Abd al-Wasif bin Muhammad, and Shaykh Yûsuf alHawi (hadith and fiqh expert). Finally, he succeeded in completing his studies and obtaining a Shahadah 'Aliyah in the field of Islamic sharia. He finally returned to Malaysia from 1967 to 1969, then returned to Egypt until 1980. In Malaysia, he received his Honorary Diploma in Doctor of Law at Universiti Kebangsaan Malaysia, and was awarded the Tokoh Maal Hijrah Kebangsaan in 1987 and the Anugerah Pingat Ahli Mahkota Perak in 1988 from Sultan Perak, Sultan Azlan Shah. ${ }^{12}$

Al-Marbawi has written a number of works in various fields. He wrote a dictionary entitled Kamus al-Marbawi, which is an Arabic-Malay dictionary in Jawi Arabic script. This dictionary is very helpful in learning Arabic and as means of reading classical Islamic religious textbooks or what is popularly known as kitab kuning. This dictionary was written in 1937 when he was still in Egypt. In the field of dictionaries and encyclopedias, he wrote Kamus al-Marbawi, Ringkasan Kamus Melayu-Arab Bergambar dan Teladan Belajar Arabnya yang Senang, al-Marbawi: Qamus al-Jayb 'Arabi-Melayu Latin, Kitab Perbendaharaan Ilmu, and Mu'jam al-Kainah. In Qur'anic exegesis studies he wrote the Tafsir Quran al-Marbawi: Juz Aliflamim and Tafsir Surah Yasin Bahasa Melayu. In hadith studies he wrote Bahrr al-Mâzi, Kitab Idangan Guru Shahîh al-Bukhârî dan Muslim, and Kitab Bulûgh al-Marâm serta Terjemah Melayu. In the field of theology, jurisprudence and sufism, he wrote the Punca Agama dan Pati Hukum Ibadat, Nizham al-Hayat, Nizham al-Hayat and Asas Islam. ${ }^{13}$ 
The most monumental ouvre written by al-Marbawi is the Bahrr al-Mâzi Syarh fi Mukhtashâr Shahîh al-Tirmizî (Sea of Honey, an Elucidation for Abridged Shahîh $\underline{h}$ al-Tirmizî). From the name, the reader will be able to describe the contents that are so broad. Indeed the explanation is broad but comprehensive. The contents are Shâfíi schools. This book consists of ten volumes, each volume consisting of two parts. The presentation system is very practical. First, the hadith is written and each line is given a word-per-word translation below the line. After that, it is given a line under the hadith text and its translation. Then written numbers accompanied by the word problem as a number of problems arising from the hadith explained. The problem statement is explained extensively to completion. After the hadith is explained at length, then enter the next hadith. This book is still widely circulated and used as reading material, in recitals, including in some pesantren.

It seems that the book of syarh or exposition is compose as such, especially in Aceh, the direction of one of al-kutub alsittah in the lifetime of Muhammad Idris al-Marbawi and the previous period does not yet exist in Malay. This means a very significant contribution to the development of the study of Hadith in the archipelago. The book Bahr r al-Mâzi was discussed in depth as a Doctoral thesis by Faisal Ahmad Shah at University of Malaya. For those of you who are deeply aware, you can read in Faisal Ahmad Shah's thesis which was published under the title "Mohammad Idris Al-Marbawi Penulis Karya Agung Bah $\underline{r}$ al-Mâzi."

\section{T.M. Hasbi Ash Shiddieqy}

T.M Hasbi Ash Shiddieqy was born on March 10, 1904 in Lhokseumawe. His father, Teuku Kadi Sri Maharaja Mangkubumi 
Hussein bin Mas'ud, was a prominent ulama in his region and owned a meunasah or what is the better known in Java as pesantren (Islamic boarding school). ${ }^{14}$ From this pesantren he began his education. After that he visited various Islamic boarding schools from one city to another to study Islam. Arabic education was obtained from Shaykh Muhammad bin Salim al-Kalali, an Arabian scholar. In 1926 he left for Surabaya and continued his education at the Madrasah al-Irshad founded by Ahmad Surkati. In Madrasah al-Irshad he took takhashshus (specialization) in the fields of education and language. The trends and patterns of thinking of T.M Hasbi Ash Shaddieqy are much influenced by these educational institutions. After returning to Aceh he immediately joined Muhammadiyah. ${ }^{15}$

Ash Shiddieqy was actively involved in the debate of Konstituante ideology representing Masyumi Party. In 1951, he settled in Yogyakarta and concentrated on education. Since 1960 he was appointed Dean of the Syari'ah Faculty of IAIN Sunan Kalijaga (State Islamic Institute of Sunan Kalijaga) of Yogyakarta until 1972. In 1960 T.M Hasbi Ash Shiddieqy was appointed as a Professor of hadith studies at IAIN Sunan Kalijaga. Three years later, in 1975 he received his doctorate (honoris causa) from the Islamic University of Bandung (UNISBA) and from the IAIN Sunan Kalijaga. ${ }^{16}$

Ash Shiddieqy is a prolific author. His work reaches 73 titles (142 volumes), 8 of which are in the field of hadith. ${ }^{17}$ In the field of theology, he wrote Pelajaran Tauhid, and the most important works in hadith studies include Sejarah dan Pengantar Ilmu Hadits, Problematika Hadits sebagai Dasar Pembinaan Hukum Islam, Rijalul hadiets, Mukhtarat min Ahadits al-Ahkam li Qism al-Dukturah al-Ula, Mutiara Hadis 1 (Keimanan), Mutiara Hadis 2 (Thaharah \& Shalat), Mutiara Hadis 3 (Shalat), Mutiara Hadis 4 (Jenazah, Zakat, Puasa, Iktikaf \& Haji), Mutiara Hadis 
5 (Nikah \& Hukum Keluarga, Perbudakan, Jual Beli, Nazar \& Sumpah, Pidana \& Peradilan, Jihad), 2002 Mutiara Hadits, 2002 Mutiara Hadits, al-Ahkam: Hukum-Hukum Fiqih Islam, Koleksi Hadits-Hadits Hukum, Kriteria Antara Sunnah dan Bid'ah Kuliyah Hadits, and Pokok-Pokok Ilmu Dirayah Hadits. In the field of Islam studies, he wrote Al-Islam: Kepercayaan, Kesusilaan, Amal Kebajikan, Al-Islam: Penuntun Bathin \& Pembimbing Masyarakat, Dasar-Dasar Ideologi Islam, and Sejarah dan Perjuangan 40 Pahlawan Utama dalam Islam. In the field of Qur'anic studies and exegesis, he wrote Al-Quran Mu'jizat yang Terbesar yang Tak Terkalahkan, Ilmu-ilmu Al-Quran: Media Pokok dalam Menafsirkan Al-Quran, Mu'jizat al-Quran, Sejarah dan Pengantar Ilmu Tafsir, Tafsir al-Bayan and Tafsir al-Quranul Majid An Nur.

In the field of Islamic legal studies, he wrote Dasar-dasar Fiqih Islam, Dasar-Dasar Kehakiman dalam Pemerintahan Islam, Fakta-fakta Keagungan Syari'at Islam, Falsafah Hukum Islam, Fiqhul Mawaris: Hukum-Hukum Warisan dalam Syariat Islam, Fiqh Islam, Hakikat Islam dan Unsur-Unsur Agama, Hukum Antar Golongan dalam Fiqih Islam, Hukum-Hukum Fiqih Islam, Hukum Perang dalam Islam, dan Ikhtisar Tuntunan Zakah dan Fithrah, Pedoman Zikir dan Do'a, Pedoman Haji, Pedoman Ibadat Puasa, Pedoman Puasa, Pedoman Shalat, Pokok-Pokok Pegangan Imam-Imam Madzhab dalam Membina Hukum Islam, Pokok-Pokok Sebab Perbedaan Paham Para Ulama/Fuqoha dalam Menetapkan Hukum Syara, Polygami Menurut Hukum Islam, Problematika Bulan Ramadhan, Problematika 'Tedul Fithri, Tuntunan Zakah dan Fithrah, Sejarah Kehakiman dalam Pemerintahan Islam, Sejarah Peradilan Islam, Sejarah Pertumbuhan dan Perkembangan Hukum Islam, Syari at Islam Adalah Syariat Dunia dan Kemanusiaan, and Syari'at Islam Menjawab Tantangan Zaman. In short, however, it is evident that T. M. Hasbi Ash Shiddieqy produced more 
works in the realm of Islamic legal studies, Qur'anic exegesis and hadith rather than in other fields.

According to Ash Shiddieqy, the authentic hadith or the sunnah Shahihah is a legal argument that should be taken into account. Accordingly, he maintained that, Sunnah is practical interpretation of the Qur'an, the teachings of which enshrined there in that obliged any Muslim to follow the al-sunnah and abide by it. Some of the sunnah functions as a reinforcement of the law stipulated by the Qur'an. As such its position then as an elaboration while others as interpretation of things that have not been confirmed in the Qur'an whether specifying the very general verses, confining absolute verses, explaining very general verses, or those verses that function to specify certain rulings in which Qur'an has not yet identified. ${ }^{18}$

In the meantime, Ash Shiddieqy also emphasized that in using Hadith, Muslims must be careful, because not all Hadith can be used as propositions, such as in the case of the very weak status of hadith and its branches. ${ }^{19} \mathrm{He}$ also reminded that the Messenger of Allah, besides being an Apostle is also an ordinary human being. The Prophet's Hadith in its capacity as an Apostle to all mankind must be obeyed. However, the Prophet's hadith in his capacity as an ordinary human or hadith that applies specifically to him is not a sharia that must be emulated. ${ }^{20}$ For example, the way the Prophet ate, dressed, walked or dressed, disliked the meat of $d h a b$, told someone suffering from stomach ailments to drink honey, armed, how to cultivate crops, and regulate war tactics, not examples that must be followed. Because, according to T. Hasbi Ash Shiddieqy, all that was done by the Prophet was based on 'urf not revelation. ${ }^{21}$

Thus, it is not surprising if he asks the Muslims that such hadiths as berbekam (to extract tainted blood from the body by using the suction method), hadith on the view that only the 
Quraysh have the right to hold the leadership (khilâfah), the hadith of the fly and the like, even though they are recorded in Shahîh al-Bukhârî, they are not an obligation to be carried out. ${ }^{22}$ According to Ash Shiddieqy, the Hadith is divided into mutawatir and ahad. The position of hadith ahad is presumptive which can not abolish the law stipulated by the Qur'an and can not specify the verses of the Qur'an unless the content is agreed upon and reach the degree of consensus (ijma) of the scholars. The weak status of Hadith could not be used to establish the law, even if the law is pertaining to habitual practice (sunnah). ${ }^{23}$

Ash Shiddieqy argues that atsar sahabi cannot be used as an argument to establish $\underline{h}$ alâl and $\underline{h}$ arâm laws. If it is found atsar contrary to the hadith, then the automatically used means is a hadith. In the meantime, he also argues, the fatwa of shahabah is mutually contradictory in one problem, so the fatwa falls. ${ }^{24}$ In the view of Ash Shiddieqy, the Hadith and Sunnah are different, even though the meanings are the same. Hadith are the Prophet's words, deeds and decision whereas Sunnah is a religious tradition that is done by the Prophet regularly and continued by his companions and salâf al-shâlih. The opponent of the Sunnah is heresy. According to him, heresy is an additional or subtractive change from the Sunnah. The forbidden heresy is adding to the matters of worship and creed. In worldly affairs, the heresy that is denounced is an additional act which is governed by Islamic teachings. Acts that are not regulated in the shariah which are not classified as worship and the tauhîd are not prohibited heretics. ${ }^{25}$

As a figure who has been educated by Madrasah al-Irsyad, of course, it is understandable why the style of Ash Shiddieqy's thinking in general has much in common with Ahmad Surkati. The same reality was also found in some Persis and Muhammadiyah figures who had come into contact with Ahmad Surkati's mindset. 
Their mindset is based on one purpose, "Return to the Qur'an and Sunnah." Moving from the goal of the desire to return to the Qur'an and the Sunnah the purified figures were encouraged to explore the Sunnah (Hadith), including Ash Shiddieqy. Therefore, even though later he was better known as a fiqh expert, this fiqh thought had been provided with sufficient knowledge in the field of Hadith. This is evident in his studies of fiqh and ushul fiqh always referring to the arguments of the Qur'an and Hadith in accordance with the rules of the science of hadith. In addition, his works on the traditions of hadith such as Pokok-Pokok Ilmu Dirayah Hadis, and Sejarah dan Pengantar Ilmu Hadis, are other proofs of his expertise in the field of Hadith. His expertise in the field of Hadith is also evidenced by the results of his work entitled, Hadis-hadis Hukum. This book is written systematically by describing the name of the ulama who perform the takhrîj al-hadits, as well as the value and the dalâlah. Anyone cannot argue that to do such a thing requires sufficient knowledge of Hadith.

It can be said that before Syuhudi Isma'il, Ash Shiddieqy was a figure who was very instrumental in the development of the science of hadith in Indonesia, especially at IAIN. The contribution can be seen from the use of syllabuses (curricula) made nationally placing his works in the field of hadith into compulsory books and recommended books for students to read up to the present time. ${ }^{26}$ However, the works of Ash Shiddieqy in the field of Hadith which seemed to be adapted and did not have time to carry out analyzes and comparisons reflect their original writings. In addition, these works also do not use adequate methodology as a scientific book. He rarely uses footnotes and analyzes the material he presents. Therefore, the works of Ash Shiddieqy in this field do not spawn new reviews but only describe the material of hadith science as it is. However, his 
works have contributed to helping students understand the science of hadith. Based on the above view, it can be stated that Ash Shiddieqy's greatest contribution in the field of hadith is to provide literature in the form of adaptations to facilitate the interest of general hadith scholars and students especially in understanding the traditions of hadith.

\section{Conclusion}

Based on the above study two conclusions can be concluded. First, al-Marbawi obtained his education inSaudi Arabia and Egypt, and studied with a number of prominent scholars. Ash Shiddieqy is an autodidact kind of ulama and has never received religious education in the Middle East. Second, in the field of Islam religious teachings, both al-Marbawi and Ash Shiddieqy developed the field of hadith or prophetic traditions, in addition to Qur'anic exegeses, theology and Islamic law. However, Ash Shiddieqy did not write in the field of Arabic in the form of a dictionary or sufism, and he did not get a sanad in the field of hadith. In contrast, al-Marbawi has a sanad in the field of hadith. However, Ash Shiddieqy was more productive in writing works in the field of Islam which numbered dozens of works in the field of theology, Qur'anic exegesis, hadith, and fiqh. But one thing is certain that the two scholars played an important role in developing and strengthening Islam in their respective countries.

\section{References}

Ash Shiddieqy, Muhammad Hasbi. "Pidato Promovendus Pada Upacara Penganugerahan Doktor Honoris Causa dalam Ilmu Syari'ah.” Yogyakarta: IAIN Sunan Kalijaga, 1975. 
Aziz, Nor Azlida. "Metodologi Pentafsiran Shaykh Muhammad Idris al-Marbawi dalam Kitab Tafsir Quran Marbawi.” Masters Thesis, University of Malaya, 2010.

Dahlan, Abdul Aziz, et al. (ed.). Ensiklopedi Hukum Islam, Vol. 2. Jakarta: Ichtiyar Baru van Hoeve, 1996.

Direktorat Jenderal Pembinaan Kelembagaan Agama Islam Perguruan Tinggi Agama Islam Departemen Agama RI. Topik Inti Kurikulum Nasional Perguruan Tinggi Agama Islam. Jakarta: Departemen Agama RI., 1998.

Hamdani, Fikri. "Hasbi Ash Shiddieqy dan Metode Penafsirannya," in Rausyan Fikr: Jurnal Studi Ilmu Ushuluddin dan Filsafat, Vol. 12, No. 1, 2016.

Hussein, Haziyah, et al. "Pemikiran Tafsir Shaykh Mohamed Idris al-Marbawi dalam Manuskrip Quran Bergantung Makna Melayu," in Jurnal Turath, Vol. 1, No. 1, 2016.

Ismatulloh, A.M. "Penafsiran M. Hasbi Ash-Shiddieqi terhadap Ayat-Ayat Hukum dalam Tafsir An-Nur," in Mazhab: Jurnal Pemikiran Hukum Islam, Vol. 13, No. 2, 2014.

Majid, Latifah Abdul \& Nurullah Kurt. "Bahr Al-Madhi: Significant Hadith Text Sciences for Malay Muslims as a Tool for Political Teaching during Twentieth Century," in Mediterranean Journal of Social Sciences, Vol. 5, No. 20, 2014.

Miswar, Andi. “Tafsir al-Qur'an al-Majid “Al-Nur” Karya T. M. Hasbi Ash Shiddieqy: Corak Tafsir Berdasarkan Perkembangan Kebudayaan Islam Nusantara," in Jurnal Adabiyah, Vol. 15, No. 1, 2015.

Nordin, Muhd. Norazam, et al. "Sumbangan Syeikh Mohamed Idris al-Marbawi dalam bidang Dakwah Islamiyyah di Malaysia," in Jurnal Maw'izah, Vol. 12018.

Shah, Faisal Ahmad. "Faktor Kejayaan dan Kecemerlangan Orang Melayu Menurut Mohamed Idris Al Marbawi," in Jurnal Pengajian Melayu, Vol. 20, No. 1, 2009. 
Shah, Faisal bin Ahmad. "Syaikh Mohamed Idris al-Marbawi: Kontribusinya dalam Fiqh al-Hadis," in MIQOT: Jurnal Ilmu-ilmu Keislaman, Vol. 34, No. 1, 2010.

Shiddiqi, Nourouzzaman. Jeram-Jeram Peradaban Muslim. Yogyakarta: Pustaka Pelajar, 1996.

Suhirman, Gatot. "Fiqh Madzhab Indonesia: Konsep dan Aplikasi Pemikiran Hasbi As-Siddiqi untuk Konteks Islam Rahmat li-Indonesia," in al-Mawarid, Vol. 11, No. 1, 2010.

Supian, Aan. "Kontribusi Pemikiran Hasbi Ash Shiddieqy dalam Kajian Ilmu Hadis," in Mutawatir: Jurnal Keilmuan Tafsir Hadis, Vol. 4, No. 2, 2014.

Tahir, Masnun. "Pemikiran T. M. Hasbi Ash Shiddieqy: Sumber $\mathrm{H}$ ukum Islam dan Relevansinya dengan Pemikiran Hukum Islam di Indonesia," in Ahwal: Jurnal Hukum Keluarga Islam, Vol. 1, No. 1, 2008. 


\section{Endnotes:}

${ }^{1}$ Faisal Ahmad Shah, "Faktor Kejayaan dan Kecemerlangan Orang Melayu Menurut Mohamed Idris Al Marbawi," in Jurnal Pengajian Melayu, Vol. 20, No. 1, 2009, pp. 26-50.

${ }^{2}$ Latifah Abdul Majid \& Nurullah Kurt, "Bahr Al-Madhi: Significant Hadith Text Sciences for Malay Muslims as a Tool for Political Teaching during Twentieh Century," in Mediterranean Journal of Social Sciences, Vol. 5, No. 20, 2014, pp. 2249-2254.

${ }^{3}$ Nor Azlida Aziz, "Metodologi pentafsiran Sheikh Muhammad Idris al-Marbawi dalam kitab Tafsir Quran Marbawi” (Masters Thesis, University of Malaya, 2010).

${ }^{4}$ Andi Miswar, "Tafsir al-Qur'an al-Majid "Al-Nur" Karya T. M. Hasbi Ash Shiddieqy (Corak Tafsir Berdasarkan Perkembangan Kebudayaan Islam Nusantara)," in Jurnal Adabiyah, Vol. 15, No. 1, 2015, pp. 83-91.

${ }^{5}$ Aan Supian, "Kontribusi Pemikiran Hasbi Ash Shiddieqy dalam Kajian Ilmu Hadis," in Mutawatir: Jurnal Keilmuan Tafsir Hadis, Vol. 4, No. 2, 2014, pp. 270-291.

${ }^{6}$ A.M. Ismatulloh, "Penafsiran M. Hasbi Ash Shiddieqi terhadap Ayat-Ayat Hukum dalam Tafsir An-Nur," in Mazhab: Jurnal Pemikiran Hukum Islam, Vol. 13, No. 2, 2014, pp. 139-152.

${ }^{7}$ Masnun Tahir, "Pemikiran T. M. Hasbi Ash Shiddieqy: Sumber Hukum Islam dan Relevansinya dengan Pemikiran Hukum Islam di Indonesia," in Ahwal: Jurnal Hukum Keluarga Islam, Vol. 1, No. 1, 2008.

${ }^{8}$ Gatot Suhirman, "Fiqh Madzhab Indonesia: Konsep dan Aplikasi Pemikiran Hasbi As-Siddiqi untuk Konteks Islam Rahmat Li-Indonesia," in al-Mawarid, Vol. 11, No. 1, 2010.

${ }^{9}$ Fikri Hamdani, "Hasbi Ash Shiddieqy dan Metode Penafsirannya," in Rausyan Fikr: Jurnal Studi Ilmu Ushuluddin dan Filsafat, Vol. 12, No. 1, 2016.

${ }^{10}$ Muhd. Norazam Nordin, et al. "Sumbangan Syeikh Mohamed Idris al-Marbawi dalam bidang Dakwah Islamiyyah di Malaysia," in Jurnal Maw'izah, Jilid 1, 2018, pp. 15-26.

${ }^{11}$ Ibid., p. 18.

${ }^{12}$ Haziyah Hussein, et al., "Pemikiran Tafsir Sheikh Mohamed Idris al-Marbawi dalam Manuskrip Quran Bergantung Makna Melayu,” in Jurnal Turath, Vol. 1, No. 1, 2016, p. 25-26.

${ }^{13}$ Faisal bin Ahmad Shah, "Syaikh Mohamed Idris al-Marbawi: Kontribusinya dalam Fiqh al-Hadis," in MIQOT: Jurnal Ilmu-ilmu Keislaman, Vol. 34, No. 1, 2010, p. 56.

${ }^{14}$ Abdul Aziz Dahlan et. al. (eds.) Ensiklopedi Hukum Islam, Vol. 2 (Jakarta: Ichtiyar Baru van Hoeve, 1996), p. 530.

${ }^{15}$ Ibid.

${ }^{16}$ Ibid. 
VOL. 3 NO. 1 JANUARI-JUNI 2019

${ }^{17}$ Ibid.

${ }^{18}$ Muhammad Hasbi Ash Shiddieqy, "Pidato Promovendus Pada Upcara Penganugerahan Doktor Honoris Causa Dalam Ilmu Syari'ah" (Yogyakarta: IAIN Sunan Kalijaga, 1975), p. 24.

${ }^{19}$ Nourouzzaman Shiddiqi, Jeram-Jeram Peradaban Muslim (Yogyakarta: Pustaka Pelajar, 1996), p. 226.

${ }^{20}$ Ibid.

${ }^{21}$ Ibid.

${ }^{22}$ Ibid.

${ }^{23}$ Ibid.

${ }^{24}$ Ibid.

${ }^{25}$ Ibid., p. 227.

${ }^{26}$ Direktorat Jenderal Pembinaan Kelembagaan Agama Islam Perguruan Tinggi Agama Islam Departemen Agama RI., Topik Inti Kurikulum Nasional Perguruan Tinggi Agama Islam (Jakarta: Departemen Agama RI., 1998), p. 148. 